\title{
Remembering Thomas Szasz
}

\section{Louis Ruffalo* \\ Psychotherapist, Carolina East Medical Center}

*Corresponding author: M. Louis Ruffalo,Adjunct Faculty, Department of Psychiatry, University of North Carolina, 1304- B Commerce Drive, New Bern, NC 28562, USA Tel: 412-916-4014; E-mail: mlruffalo@gmail.com

Received Date: September 4, 2014, Accepted Date: September 23, 2014, Published Date: September 30, 2014

Copyright: $\odot 2014$, M. Louis Ruffalo, This is an open-access article distributed under the terms of the Creative Commons Attribution License, which permits unrestricted use, distribution, and reproduction in any medium, provided the original author and source are credited.

\section{Short Communication}

Two years ago, Thomas Stephen Szasz passed away at his home in upstate New York at the age of 92. Best known as the author of the controversial 1961 book The Myth of Mental Illness, Szasz served for many years as professor of psychiatry at the State University of New York and authored hundreds of books and articles over the course of his life. He was a lifetime fellow of the American Psychiatric Association, a life member of the American Psychoanalytic Association, and one of the most influential psychiatrists and social critics of the 20th Century. Yet, his many contributions to the fields of psychiatry and psychoanalysis are dismissed by contemporary mental health professionals as "outdated" and "irrelevant," outside of a select few intellectuals in academia. I believe that this perspective stems from a deep misunderstanding about the nature of Szasz's work and the meaning of Szasz's arguments. I feel very fortunate to have communicated with Dr. Szasz on numerous occasions while I was in graduate school and after I began my career, and consider him to be my personal and professional mentor. Szasz's work is particularly relevant to social workers who have an interest in the social context of psychiatry.

The central moral principle underlying all of Dr. Szasz's published work-and indeed Dr. Szasz's life-is the principle of individual autonomy. Autonomy can be defined as the right of every individual to pursue their own goals in life, to choose among alternative courses of action so long as no injury occurs to other people. It is a concept closely related to the social work ethical principle of self-determination and also to concepts such as self-ownership and freedom of thought. Dr. Szasz placed heavy emphasis on autonomy because he viewed liberty to be among the most important-and most vulnerable-of human causes. He was a lifelong libertarian and an adjunct scholar at the Cato Institute, a libertarian think tank in Washington, DC. Looking back to the early period of Szasz's life, it is easy to see why he may have developed an affinity for freedom: he grew up under the threat of communism in Eastern Europe and his family came to the United States to escape Hitler when Szasz was a teenager [1-3].

Dr. Szasz's writings about psychiatry usually fall into one of two areas (and frequently both areas simultaneously). These areas are: the medicalization of human problems in living as psychiatric diseases (the myth of mental illness or the mental illness metaphor), and the use of psychiatry to justify depriving persons of liberty and responsibility (involuntary psychiatric hospitalization and the insanity defense). I will attempt to explain briefly Dr. Szasz's ideas as they relate to both of these areas and to clarify some of the common misunderstandings and misconceptions about Dr. Szasz's basic beliefs and assumptions.

Dr. Szasz is frequently criticized for "not believing in mental illness." This belief has been echoed for many, many years in university lecture halls, training institutes and hospitals, and in the professional literature. But it is only half-correct. Szasz maintained throughout his career that mental illness is illness only in the metaphorical sense and that psychiatric disorders do not meet any of the established pathophysiological criteria for classification of disease. "Strictly speaking, disease or illness can affect only the body; hence there can be no mental illness," Szasz (1961) wrote. Indeed, he viewed "mental illness" as a contradiction of terms. However, he did not, as many people like to claim, deny the existence of what one may call "psychiatric symptoms." He recognized that these experiences exist, that people can be troubled by them, and that there is a role for a professional to help these individuals. He was not "anti-psychiatry" or an "anti-psychiatrist." He was anti-coercive psychiatry. He preferred the term "problems in living" to describe the target of psychiatric and psychotherapeutic interventions.

Recent advances in biological research do not, as some claim, negate or invalidate Szasz's premise. All human behavior can be said to be "biologically-based" in the sense that it is initiated by the body. But the classification of behavior (including mental behavior) as disease always relies upon the social context and is influenced by a range of different values and objectives. (In fact, Szasz was the first American psychiatrist to speak out against the classification of homosexuality as a mental disorder). Whereas in medicine diseases are discovered using objective scientific tests, in psychiatry they are invented by committees of psychiatrists who vote on whether this or that behavior or set of behaviors constitutes a mental disorder. Dr. Szasz contended that the classification of behavior as disease represents a basic category error. Because he did not view his patients as sick in any medically meaningful sense of the term, Dr. Szasz did not prescribe medication to his patients and preferred instead to practice a form of psychoanalysis he called "autonomous psychotherapy" aimed at restoring patients' sense of freedom and self-responsibility. He viewed personal autonomy as Freud's original goal for psychoanalysis. (See The Ethics of Psychoanalysis: The Theory and Method of Autonomous Psychotherapy, 1965.)

While he was completing his psychiatry residency and his psychoanalytic training, Dr. Szasz did not treat a single involuntary patient due to his deep moral and ethical convictions to the principle of individual liberty. It was these convictions that also led him to limit his professional work to voluntary clients and to oppose the practices of the insanity defense and involuntary hospitalization (which he sometimes referred to as "psychiatric imprisonment"). Dr. Szasz did not hospitalize a single patient during his psychiatric career. Critics of Szasz often claim that his opposition to involuntary treatment was unethical because he unnecessarily placed individuals at risk for harm, specifically self-harm. But Szasz's position on suicide was simple: Included in a person's right to life is the right to death. Individuals are the owners of their own bodies. This is not to say that therapists should not attempt to dissuade persons from suicide. Rather, individuals 
should not be forcibly prohibited by the state or by a mental health professional from taking their own life. Szasz's position on the insanity defense was also founded on the concept of self-responsibility: if mental illness is metaphor, then insanity as a legal concept serves only to deprive persons of responsibility for their actions and excuse criminal behavior.

Perhaps the most interesting historical piece relating to psychiatry that I have ever come across is a personal letter to Thomas Szasz from the late Dr. Karl Menninger, authored in 1988, shortly before Menninger's death. Dr. Menninger has been described as the long-time "dean" of American psychiatry and was a co-founder of the prestigious Menninger Clinic for psychiatric disorders in Topeka, Kansas. The letter was in response to Szasz's book Insanity: The Idea and Its Consequences, which Szasz sent to Menninger as a gift. In the letter, Menninger expressed agreement with Szasz's fundamental views: "I think I know what it says but I did enjoy hearing it said again. I think I understand better what has disturbed you these years and, in fact; -it disturbs me, too, now. We don't like the situation that prevails whereby a fellow human being is put aside, outcast as it were, ignored, labeled and said to be 'sick in his mind." Throughout the letter, Menninger places the words "sickness," "diagnosis," and "treatment" in quotation marks, suggesting that he had come to agree with Szasz about the metaphorical and existential nature of mental illness. Szasz responded by expressing deep admiration for Dr. Menninger and asking Menninger if he could cite the letter for future use, calling it a "piece of psychiatric history," which, of course, it was. Menninger knew this, and permitted its citation. Mea culpa.
While psychiatrists and other mental health professionals continue to denounce Dr. Szasz as a "flat-earther" who denied the "reality" of mental illness, his ideas live on in disciplines such as sociology and philosophy. Even within academic psychiatry, Dr. Szasz's ideas continue to have bearing. There is no need to look any further than Dr. Allen Frances's recent warnings about medicalization and pathologization in psychiatric diagnosis to see the impact Dr. Szasz has had on contemporary psychiatric thought and reason. The world lost a staunch defender of human liberty and freedom when it lost Dr. Thomas Szasz. But although Thomas Szasz, the man, may have passed, Thomas Szasz, the idea of human freedom, lives on. It is now our duty and responsibility to continue Dr. Szasz's work in defense of liberty.

M. Louis Ruffalo, M.S.W., is a psychoanalytic psychotherapist in practice in New Bern, North Carolina. He serves on staff at CarolinaEast Medical Center in New Bern, has a solo private practice of psychotherapy, and is an adjunct faculty member in psychiatry at the University of North Carolina.

\section{References}

1. Menninger KA (1989) Reading notes. Bulletin of the Menninger Clinic 53: 350-352.

2. Szasz TS (1961) The myth of mental illness: Foundations for a theory of personal conduct. New York, NY: Harper \& Row.

3. Szasz TS (1965) The ethics of psychoanalysis: The theory and method of autonomous psychotherapy. New York, NY: Basic Books. 